\title{
Role of respiratory viruses in infants less than six months of age with upper respiratory tract infections
}

\section{Altı ay altındaki süt çocuklarında üst solunum yolu enfeksiyonlarında solunum yolu viruslarının rolü}

\section{Eda Karadag-Öncel ${ }^{1}$, Demet Baser ${ }^{2}$, Ayça Kömürlüoğlu ${ }^{3}$, Meral Ciblak ${ }^{4}$, Yasemin Özsürekçi ${ }^{1}$, Cihangul Bayhan ${ }^{1}$, Selim Badur ${ }^{4}$, Mehmet Ceyhan ${ }^{1}$}

${ }^{1}$ Hacettepe University Faculty of Medicine, Department of Pediatric Infectious Diseases, Ankara, Turkey

${ }^{2}$ Batman State Hospital, Department of Pediatrics, Batman, Turkey

${ }^{3}$ Gürün State Hospital, Sivas, Turkey

'Istanbul University Faculty of Medicine, National Influenza Laboratory, Istanbul, Turkey

Corresponding author: Ayça Kömürlüoğlu M.D, Gürün State Hospital, Sivas, Turkey

E-mail: akomurluoglu@hotmail.com

Received/Accepted: March 29,2017 / June 5, 2017

Conflict of interest: There is not a conflict of interest.

\section{SUMMARY}

Objective: With a wide range of clinical presentations, respiratory tract infections remain a significant cause of morbidity and mortality worldwide, particularly in infants. The aim of this cross-sectional descriptive study was to determine the frequency of respiratory viruses responsible for upper respiratory tract infections during the 2013-2014 influenza season in infants less than 6 months of age.

Method: Nasal swabs were obtained from patients with symptoms suggestive of an influenza-like illness (ILI) between January and April 2014. Specimens were evaluated by RT-PCR to help identify the causative viral pathogens.

Results: A total of 150 patients with ILI were enrolled in the study. A respiratory virus was successfully detected in 126 $(\underline{86 \%})$ infants; RSV in $41(32.5 \%)$, rhinovirus in $17(13.4 \%)$, metapneumovirus in $15(11.9 \%)$, coronavirus in $11(8.7 \%)$, adenovirus in $5(3.9 \%)$, parainfluenza virus in $2(1.5 \%)$ and bocavirus in $2(1.5 \%)$ infants. Thirty-three $(26.1 \%)$ patients were found to be co-infected with both two viruses. Rhinorrhea and developing complications were significantly more frequently seen in RT-PCR positive patients ( $p=0.023$ and $p=0.019$, respectively). All complications were seen in RTPCR positive group, especially in metapneumovirus, RSV and multiple viruses positive patients.

Conclusions: With an overall viral pathogen detection rate of $\underline{86 \%}$, findings of our study present that influenza viruses were not seen in infants less than 6 months of age in our study population, whether RSV and multiple viral infections were the most common causes in this age group.

Keywords: infants, influenza-like illness, real-time PCR, respiratory viruses

\section{ÖZET}

Amaç: Solunum yolu enfeksiyonları tüm dünyada özellikle süt çocuklarında mortalite ve morbiditenin önemli bir nedenidir. Bu kesitsel- tanımlayıcı çalışmanın amacı, 6 ay altındaki süt çocuklarında 2013-2014 influenza sezonu boyunca üst solunum yolu enfeksiyonlarından sorumlu olan solunum yolu viruslarınin saptanmasidır.

Yöntem: Ocak - Nisan 2014 tarihleri arasında akut üst solunum yolu enfeksiyonu (ÜSYE) semptomları ile başvuran hastalardan nazofaringeal sürüntü (swab) alındı. Örneklerden solunum yolu virusları için RT-PCR çalış1ldı.

Bulgular: 150 hasta çalışmaya alındı. $126(\underline{\%})$ hastada solunum yolu virusları pozitif bulundu. Virus pozitif hastaların 41 'inde (\% 32.5) RSV, 17 'sinde (\% 13.4) rinovirus, 15 'inde (\% 11.9) metapnömovirus, 11 'inde (\% 8.7) koronavirus, beşinde (\% 3.9) adenovirus, ikisinde (\% 1.5) parainfluenza ve ikisinde (\% 1.5) bokavirus saptand1. Otuz üç (\% 26.1) hastanın iki virusle ko-enfeksiyonu olduğu tespit edildi. Burun akıntısı ve komplikasyon gelişimi RT-PCR pozitif hastalarda daha fazla idi (sırasıyla $\mathrm{p}=0.023$ ve $\mathrm{p}=0.019$ ). Tüm komplikasyonlar RT-PCR pozitif grupta özellikle metapnömovirus, RSV ve çoklu virus pozitif hastalarda görüldü.

Sonuç: Viral patojen pozitifliği $\% 86$ saptanan çalışmamızda, 6 ay altındaki süt çocuklarında influenza virusu görülmediği, RSV ve çoklu viral enfeksiyonların bu yaş grubunda en sik neden olduğu ortaya konmuştur.

Anahtar sözcükler: süt çocuğu, influenza benzeri hastalık, RT-PCR, solunum yolu virusları 


\section{INTRODUCTION}

Respiratory tract infections (RTIs) are a leading cause of infectious disease-related morbidity, hospitalization, and mortality among children worldwide, particularly in developing countries and in young children ${ }^{1}$. Regardless of geographic location, the most common etiologic agents acute respiratory illnesses in children are viruses ${ }^{2}$. It is associated with high annual attack rates as well as being responsible for frequent outpatient visits and hospitalizations. Young children, especially under 2 years, are more prone to being hospitalized due to a respiratory viral infection, and also this age group is at high risk for infection-related complications, including otitis media, croup, bronchitis, and pneumonia ${ }^{1,2}$. The burden of respiratory viral infections is unknown in developing countries. It is also known that in developed countries RTIs have an important socioeconomic impact due to school and work absenteeism, despite mostly having a self-limiting clinical course ${ }^{3,4}$.

Respiratory syncytial virus (RSV), seasonal influenza viruses and rhinovirus (RV) are the most common causes of respiratory infections and hospital admissions in children ${ }^{2,5}$. In infants under one year RV, RSV, bocavirus, influenza A, coronavirus and parainuenza 3 are mainly observed $^{6}$. Not only influenza viruses but also other respiratory tract viruses cause influenza-like illness (ILI) and the distinction is difficult on the basis of signs and symptoms alone. Most respiratory virus infections in neonates and young infants are limited to the upper respiratory tract and the first clinical symptoms are generally rhinorrhea, nasal congestion and cough. Fever less frequently seen in neonates and young infants but occasionally come along with lethargy and poor feeding ${ }^{6,7}$. The virological diagnosis of infants treated as outpatients is not always necessary but it is useful for predict the severity or length of the disease ${ }^{7}$. Especially in hospitalized patients prompt identification of viruses is critical to avoid unnecessary antibiotics, to start early antiviral treatment and to control the spread of infection. The aim of our study is to evaluate the respiratory viruses and associated clinical symptoms in infants younger than 6 months who present with ILI.

\section{MATERIAL AND METHODS}

Prospective surveillance was conducted to describe the spectrum of viral etiologies of acute RTIs in children less than 6 months of age. This study was undertaken in Hacettepe University Medical Faculty Ihsan Dogramac1's Child Hospital, Ankara and Batman State Hospital, Batman with the approval of the Ethical Committee. The parent or legal guardians of infants aged $<6$ months presenting between January and April 2014 with a suspicion of an acute RTI were approached, and following informed consent patients were screened for eligibility before being enrolled in the study. Acute respiratory illness defined as a maternal report of illness, with a respiratory symptom including cough, nasal congestion, rhinorrhea, breathing difficulties. Fever was defined as a tympanic temperature $\geq 37.8^{\circ} \mathrm{C}$. This definition of respiratory illness with fever was modified for infants from Centers for Disease Control and Prevention (CDC) definition of ILI ${ }^{8}$. A surveillance questionnaire was completed for each patient on which information regarding patient age, onset of symptoms, presence of an underlying chronic disorder, family member with reported ILI, family size, presence of older siblings in daycare or school, smoking at home and family member vaccinated against influenza was recorded by a pediatrician.

On their initial visit, all patients were subjected to a thorough physical examination during which their body temperatures were recorded. Nasal swab specimens were then collected from all participants according to a standard operating protocol put forth by the CDC. The procedure involves insertion of a sterile cotton swab into a nostril and each sample obtained at a depth $2-3 \mathrm{~cm}$ is then inoculated into a vial containing M4 viral transport medium (Medical Wire \& Equipment, UK).

Parents were also questioned regarding the use of medications (antipyretics, antibiotics, antivirals, etc.) during the course of the disease. Patients who developed complications or required hospitalization were identified and relevant information was recorded.

Samples obtained from each patient were stored and transported to the Virology Laboratory of Istanbul University to be tested for the presence of viral pathogens by RT-PCR within 72 hours of collection. FTD Respiratory $21 \circledR$ was used according to manufacturer's instructions (Fasttrack Diagnostics Ltd, Sliema, Malta) following total nucleic acid extraction; allowing simultaneous detection and identification of the following respiratory viruses: influenza $\mathrm{A}, \mathrm{H} 1 \mathrm{~N} 1$, influenza B, RV, coronavirus NL63, 229E, OC43, HKU1, parainfluenzavirus (PIV) 1, 2, 3, 4, human metapneumovirus (hMPV) A/B, bocavirus, Mycoplasma pneumoniae, RSV A/B, adenovirus, enterovirus, parechovirus and internal control. 


\section{Statistical Analysis}

Statistical analyses were performed using the commercial package SPSS for Windows version 17.0 (Chicago, IL, USA). Values for numerical variables were provided as mean \pm standard deviation or median (minimum-maximum), depending on normality of distribution. Categorical variables were given as numbers and percentage. For numerical variables, two-group comparisons were made using the Mann Whitney $\mathrm{U}$ test. Comparisons between groups for categorical variables were made using the Chi-square test. Associations with a $p$-value $<0.05$ were considered statistical significant.

\section{RESULTS}

During the study period, 150 nasal swab were analyzed for respiratory viruses. Four samples were excluded due to inappropriate material for analysis. Of the 146 participants, 80 (54.8\%) were male, and the average age of the children enrolled was $3.50 \pm 1.62$ months (range 7-179 days). Among the 146 children included in the study $95.9 \%$ were reported as previously healthy. At admission nasal congestion was present in $124(84.9 \%)$ of the patients, followed by cough $(\mathrm{n}=122 ; 83.5 \%)$, rhinorrhea $(n=98 ; 67.1 \%)$, restlessness $(n=95$, $65 \%)$ and difficult breathing $(n=73 ; 50 \%)$. Fever was seen in only $52(35.6 \%)$ cases. The most common complication and clinical diagnosis, as determined by attending physicians, was bronchiolitis $(\mathrm{n}=20 ; 71.4 \%)$, followed by pneumonia $(\mathrm{n}=8 ; 28.5 \%)$.

At least one virus was detected in $86.3 \%$ of children and multiple pathogens were identified in 33 children (26.2\%). A comparison of demographic and clinical findings in groups with or without virus detection revealed that infected patients had rhinorrhea and complications more frequently $(\mathrm{p}=0.024$ and $\mathrm{p}=0.01$, respectively). Demographic and clinical characteristics of the participants are shown in Table 1.

Table 1. Comparison of the demographic and clinical findings between virus detected and not detected groups presenting with influenza-like illnesses

\begin{tabular}{|c|c|c|c|}
\hline th & $\begin{array}{l}\text { RT-PCR- } \\
\text { positive } \\
(\mathrm{n}=126)\end{array}$ & $\begin{array}{c}\text { RT-PCR- } \\
\text { negative } \\
(\mathbf{n}=20)\end{array}$ & $p$-value \\
\hline \multicolumn{4}{|l|}{ Demographic characteristics } \\
\hline Age, months ${ }^{\mathrm{a}}$ & $3.50 \pm 1.64$ & $3.60 \pm 1.69$ & 0.817 \\
\hline Male gender ${ }^{\mathrm{b}}$ & $70(55.5)$ & $10(50)$ & 0.410 \\
\hline Family member with reported ILI ${ }^{\mathrm{b}}$ & $75(59.5)$ & $11(55)$ & 0.426 \\
\hline Family size $^{\mathrm{a}}$ & $5.40 \pm 2.36$ & $5.15 \pm 1.22$ & 0.638 \\
\hline $\begin{array}{l}\text { Older sibling(s) in day care or } \\
\text { school }^{\text {b }}\end{array}$ & $64(50.7)$ & $13(65)$ & 0.183 \\
\hline Smoking at home $\mathrm{b}^{\mathrm{b}}$ & $83(65.8)$ & $14(70)$ & 0.484 \\
\hline $\begin{array}{l}\text { Family member vaccinated against } \\
\text { influenza }^{\text {b }}\end{array}$ & $3(2.3)$ & $1(5)$ & 0.451 \\
\hline \multicolumn{4}{|l|}{ Clinical symptoms } \\
\hline Fever ${ }^{\mathrm{b}}$ & $45(35.7)$ & $7(35)$ & 0.582 \\
\hline Cough $^{\mathrm{b}}$ & $107(84.9)$ & $15(75)$ & 0.209 \\
\hline Nasal congestion $^{\mathrm{b}}$ & $108(85.7)$ & $16(80)$ & 0.353 \\
\hline Rhinorrhea $^{\mathrm{b}}$ & $89(70.6)$ & $9(45)$ & 0.024 \\
\hline Difficult breathing ${ }^{\mathrm{b}}$ & $66(52.4)$ & $7(35)$ & 0.114 \\
\hline Restlessness $^{\mathrm{b}}$ & $81(64.3)$ & $14(70)$ & 0.410 \\
\hline Fatigue $^{\mathrm{b}}$ & $61(48.4)$ & $7(35)$ & 0.191 \\
\hline Feeding problems ${ }^{\mathrm{b}}$ & $59(46.8)$ & $6(30)$ & 0.121 \\
\hline Complications $^{\mathrm{b}}$ & $28(22)$ & $0(0)$ & 0.010 \\
\hline Hospitalization $^{\mathrm{b}}$ & $43(34.1)$ & $5(25)$ & 0.297 \\
\hline
\end{tabular}


In positive group, RSV was most commonly identified in 41 children (32.5\%), followed by RV (13.5\%, 17/126), hMPV (11.9\%, 15/126), coronavirus $(8.7 \%, 11 / 126)$ and adenovirus $(3.9 \%$, 5/126). Among coronaviruses 6 (4.7\%) were 229E; $5(3.9 \%)$ were OC43. Each two specimens $(1.6 \%$, 2/126) yielded bocavirus type 2 and parainfluenza virus type 2 (Table 2). RSV was most frequently involved in co-infections $(\mathrm{n}=16)$, followed by coronavirus $(n=15)$, adenovirus $(n=11)$ and $R V(n=$ 10). Among RSV cases, co-infection with coronavirus was the most frequent (6/16), followed by RV (3/16) and bocavirus (3/16).

Table 2. Distribution of viral respiratory tract pathogens in patients with virus positive

\begin{tabular}{cc}
\hline Viruses $(\mathrm{n}=126)$ & $\mathrm{n}(\%)$ \\
\hline RSV & $41(32.5)$ \\
Rhinovirus & $17(13.5)$ \\
Human metapneumovirus & $15(11.9)$ \\
Coronavirus & $11(8.7)$ \\
$229 \mathrm{E}$ & $6(4.7)$ \\
OC43 & $5(3.9)$ \\
Adenovirus & $5(3.9)$ \\
Bocavirus & $2(1.6)$ \\
Parainfluenza virus & $2(1.6)$ \\
Multiple pathogens & $33(26.2)$ \\
\hline
\end{tabular}

Overall in single and multiple pathogens RSV and $\mathrm{RV}$ were the most common viruses detected, in $45.2 \%$ (41 in single and 16 in multiple) and $21.4 \%$ (17 in single and 10 in multiple) of samples, respectively. Comparison of symptoms revealed cough (\%96.5 vs \%3.5, p<0.001), rhinorrhea (\%78.9 vs \%21.1, $\mathrm{p}=0.011)$, fatigue (\%64.9 vs $\% 35.1, \mathrm{p}<0.001)$, restlessness $(\% 77.2$ vs \%22.8, $\mathrm{p}=0.011)$ and feeding problems $(\% 61.4 v s \% 38.6$, $\mathrm{p}=0.001$ ) to occur more frequently with the RSV viruses compared to the other viruses. However the median age of children with RSV (single and coinfections) was similar to other pathogens (3.24 \pm 1.76 vs $3.69 \pm 1.54$, $\mathrm{p}=0.106)$. In $\mathrm{RV}$ positive patients, cough was more common compared to other viruses (\%70.4 vs \%29.6, $\mathrm{p}=0.044)$.

Among the demographic and clinical characteristics evaluated according to viral agents, the frequency of complications were found to be associated with a significantly increased in some viral infections $(p=0.004)$, with no significant difference in association with history of house member with similar symptoms, presence of a smoker in the household, using any antipyretics or antibiotics ( $>0.05$ for all parameters). All complications were seen in positive group $(n=28)$ and the difference was statistically significant $(\mathrm{p}=0.01)$. Complications were mostly seen in hMPV (33.3\%, 5/15), RSV (29.3\%, 12/41), multiple viruses $(24.2 \%, 8 / 33)$.

Monthly distribution was observed according to viral pathogens $(\mathrm{p}=0.005)$, detected rates were higher in February and March. Between January and April 2014, most of the cases in whom RSV was detected presented in February and March similar to multiple viruses, whereas in April none of the RSV case was presented, RV cases started presenting in January, peaking in February, with cases also presenting in April (Figure 1). 


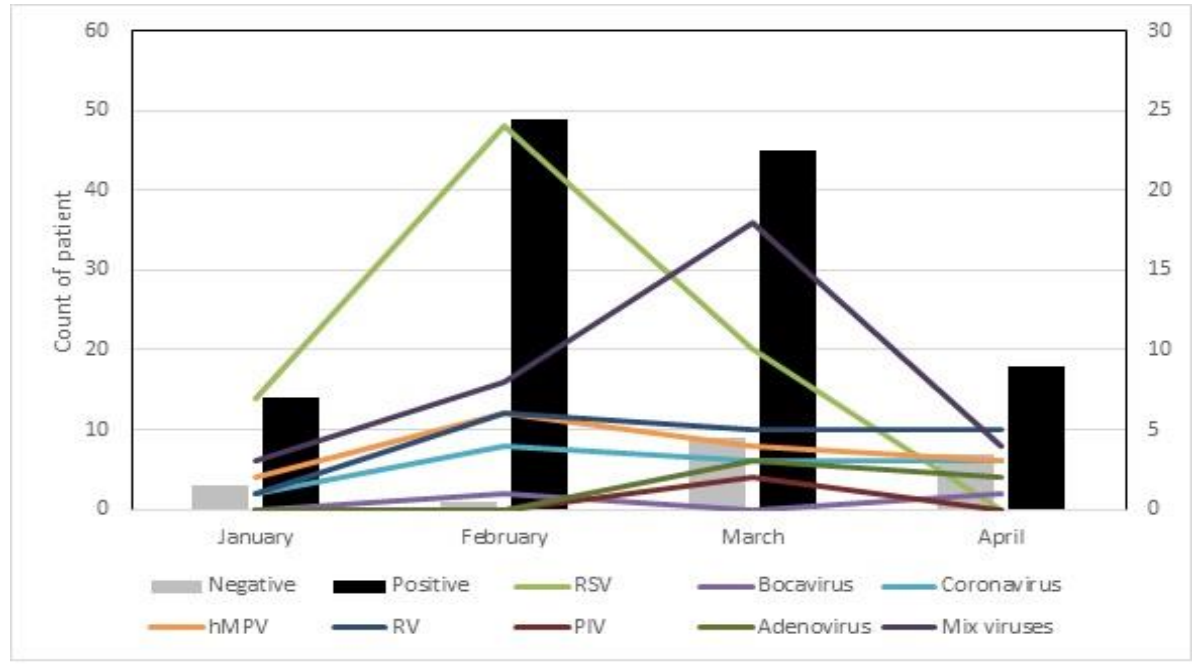

Figure 1. Monthly distribution of respiratory tract viruses

\section{DISCUSSION}

The aim of the current study was to determine the frequency and types of different clinical symptoms among infants younger than 6 months old-a population who cannot receive influenza vaccine. In our study, $86 \%$ of respiratory tract samples were positive for a viral infection and this rate was higher compared to other studies in the literature $2,9,10$. This difference is thought to be due to the fact that children in all age groups were included in other studies. RSV, influenza, RV, adenovirus, and parainfluenza viruses are considered to be important pathogens in the etiology of respiratory virus infections. Ambrosion et al showed that positivity rate in the pediatric population reached nearly $80 \%$. The high positivity rate were partially attributed to collection method of samples (nasopharyngeal aspirates) in pediatric population and the other reason was significantly higher viral load in children than in adults ${ }^{11}$. During the past decade, improvements in detection techniques have contributed to an increase in sensitivity and discovery of new respiratory viruses, such as hMPV, novel strains of coronaviruses (NL63, 229E, OC43, HKU1), and human bocavirus. The diagnostic viral kit used in this study allowed for the detection of a wider variety of viruses, which has high specifity and sensitivity ${ }^{12}$. Apart from new developed viral kits, several studies also showed that seasonal, environmental and socioeconomic factors can play a role in altering the viral test results ${ }^{9,10}$.

Overall, RSV was the most frequently detected virus, and accounted for $45.2 \%$ of single and multiple infections in children less than 6 months old. Khamis et al. ${ }^{13}$ demonstrated in their study that RSV infection occurred solely in children aged under 2 years of age, with $57 \%$ of infections occurring in infants younger than 6 months. Luchsinger et al. ${ }^{14}$ observed that in infants under 6 months of age, RSV and RV were most commonly isolated viruses and RSV in particular can lead to a more serious clinical condition. Our study showed similar results so that in patients with RSV infection, lower respiratory tract infections and bronchiolitis were more common. While respiratory complications were significantly higher in children infected with H1N1 infection compared with other influenza viruses ${ }^{5}$. In our study, none of the cases had influenza infection and complications were frequently seen in hMPV, RSV and multiple viruses. Mistry et al. ${ }^{5}$ noted that children with neurologic and neuromuscular conditions were at higher risk of developing severe complications and no specific respiratory virus was associated with development of severe complications. Most of our study population was healthy, only one patient had neurometabolic disease and severe complications were not seen in this patient.

The rates of infections with multiple viral etiologies vary among different studies. Zhang et al. ${ }^{15}$ showed a co-infection rate of $29.5 \%$ under age of 3 years old. Kouni et al. ${ }^{16}$ demonstrated that in children at ages 1 month-14 years, the co-infection rate was \%42.5. The effect of multiple viral etiologies on clinical picture has not been clearly demonstrated, however a study showed severe symptoms with co-infections ${ }^{16}$. Moreover, it is unknown whether an initial viral infection helps prevent or increase risk for future viral infections. In the current study, we found that complications were common in multiple viral infections but hospitalization rate was similar to other viral infections. 
Although our study does not represent nationwide data, it gives clues regarding viral etiologies in infants under age 6 months. None of the patients had influenza virus and the absence of influenza viruses is likely due to the low prevalence of influenza virus infection in 2013-2014 influenza season. And it should also be remembered that the infection rates vary among years. In this patient population for whom influenza vaccine cannot be administered, the prevalence of influenza infection was low, however one should remember that this might have seasonal variation. The most common virus in this patient population is RSV. Both admission and clinical complication rates are higher in patients who have RSV infection. In winter, among children who present with ILI along with lower respiratory tract symptoms, it may be important to demonstrate RSV infection for isolation of sick children and prevent the spread of the infection. Moreover, the demonstration of the viral etiologies will limit unnecessary antibiotic use as well.

Acknowledgements: We thank Sevilay Karahan (Hacettepe University Faculty of Medicine, Ankara, Turkey) for the statistical analyses.

\section{Funding: None}

\section{REFERENCES}

1. Williams BG, Gouws E, Boschi-Pinto C, Bryce J, Dye C. Estimates of world-wide distribution of child deaths from acute respiratory infections. Lancet Infect Dis 2002; 2: 25-32.

2. Cilla G, Onate E, Perez-Yarza EG, Montes M, Vicente D, Perez-Trallero E. Viruses in community-acquired pneumonia in children aged less than 3 years old: High rate of viral coinfection. J Med Virol 2008; 80: 1843-9.

3. Bramley TJ, Lerner D, Sames M. Productivity losses related to the common cold. J Occup Environ Med 2002; 44:822-9.

4. Fendrick AM, Monto AS, Nightengale B, Sarnes M. The economic burden of noninfluenza-related viral respiratory tract infection in the United States. Arch Intern Med 2003; 24:487-94.

5. Mistry RD, Fischer JB, Prasad PA, Coffin SE, Alpern ER. Severe complications in influenza-like illnesses. Pediatrics 2014; 134: 684-90.

6. Anders KL, Nguyen HL, Nguyen NM, Van Thuy NT, Hong Van NT, Hieu NT, et al. Epidemiology and virology of acute respiratory infections during the first year of life: a birth cohort study in Vietnam. Pediatr Infect Dis J 2015; 34: 361-70.
7. Luoto R, Jartti T, Ruuskanen O, Waris M, Lehtonen L, Heikkinen T. Review of the clinical significance of respiratory virus infections in newborn infants. Acta Paediatr. 2016; 105: 1132-9.

8. CDC. Seasonal influenza (flu)—FluView Interactive. Available at: www.cdc.gov/flu/weekly/ fluviewinteractive.htm. Accessed October 8, 2013

9. Karadag-Oncel E, Ciblak MA, Ozsurekci Y, Badur S, Ceyhan M. Viral etiology of influenza-like illnesses during the influenza season between December 2011 and April 2012. J Med Virol 2014; 86: 865-71.

10. Brittain-Long R, Nord S, Olofsson S, Westin $\mathrm{J}$, Anderson LM, Lindh M. Multiplex realtime PCR for detection of respiratory tract infections. J Clin Virol 2008; 41: 53-6.

11. Ambrosioni J, Bridevaux PO, Wagner G, Mamin A, Kaiser L. Epidemiology of viral respiratory infections in a tertiary care centre in the era of molecular diagnosis, Geneva, Switzerland, 2011-2012. Clin Microbiol Infect 2014; 20: 578-4.

12. Drieghe S, Ryckaert I, Beuselinck K, Lagrou K, Padalko E. Epidemiology of respiratory viruses in bronchoalveolar lavage samples in a tertiary hospital. J Clin Virol 2014; 59: 20811.

13. Khamis FA, Al-Kobaisi MF, Al-Areimi WS, Al-Kindi H, Al-Zakwani I. Epidemiology of respiratory virus infections among infants and young children admitted to hospital in Oman. J Med Virol 2012; 84: 1323-9.

14. Luchsinger V, Ampuero S, Palomino MA, Chnaiderman J, Levican J, Gaggero A, et al. Comparison of virological profiles of respiratory syncytial virus and rhinovirus in acute lower tract respiratory infections in very young Chilean infants, according to their clinical outcome. J Clin Virol 2014; 61: 13844.

15. Zhang $\mathrm{G}, \mathrm{Hu} \mathrm{Y}$, Wang $\mathrm{H}$, Zhang L, Bao Y, Zhou $X$. High incidence of multiple viral infections identified in upper respiratory tract infected children under three years of age in Shanghai, China. PLoS ONE 2012; 7: 44568.

16. Kouni S, Karakitsos P, Chranioti A, Theodoridou M, Chrousos G, Michos A. Evaluation of viral co-infections in hospitalized and non-hospitalized children with respiratory infections using microarrays. Clin Microbiol Infect 2013; 19: 772-7. 